\title{
SECOND ORDER STRUCTURAL THEORY FOR THE STABILITY ANALYSIS OF COLUMNS
}

\author{
V.V. GALISHNIKOVA, T.H. GEBRE, S.A.M. AL-SABRI, O. SAFFIA-DOE \\ Peoples' Friendship University of Russia (RUDN University) \\ 6 Mikluho-Maklaya St., Moscow, 117198, Russia \\ (received: January 04, 2018; accepted: April 05, 2018)
}

\begin{abstract}
Stability analysis in civil engineering is traditionally centred on the stability of individual components of a structure, rather than on the stability of the assemblage of structural components. This may be explained by the lack of adequate tools for the stability analysis of complete structures in the past. Recently, the necessity of the development of general rational methods of stability analysis with a model of the complex structure is widely recognized. These methods should reliably predict the overall stability of the structure, the interaction between the components of the structure in providing restraint against instability of individual members, and the local stability of each individual member. Development of such theories and corresponding algorithms require a thorough investigation. The aim of this paper is to investigate the instability of single columns without large deflections by means of the second order structural theory and to study the influence of imperfections on the behaviour of such structural elements.
\end{abstract}

Keywords: columns, stability of the structure, investigate the instability, structural elements

\section{ТЕОРИЯ ВТОРОГО ПОРЯДКА В РАСЧЕТАХ УСТОЙЧИВОСТИ КОЛОНН}

\author{
В.В. ГАЛИШНИКОВА, Т.Х. ГЕБРЕ, С.А.М. АЛЬ-САБРИ, О. САФФИА-ДОЕ \\ Российский университет дружбы народов \\ ул. Миклухо-Маклая, 6, Москва, Россия, 117198
}

(поступила в редакиию: 4 января 2018 г.; принята к публикации: 5 апреля 2018 г.)

\begin{abstract}
Анализ устойчивости в строительстве традиционно ориентирован на устойчивость отдельных компонентов конструкции, а не на устойчивость конструктивной системы в целом. Это может быть объяснено отсутствием адекватных инструментов для анализа устойчивости сложных структур в прошлом. В последнее время широко признана необходимость разработки общих рациональных методов анализа устойчивости при помощи моделирования конструктивной системы. Эти методы должны надежно прогнозировать общую устойчивость структуры, взаимодействие между ее элементами при обеспечении устойчивости отдельных элементов и устойчивость каждого отдельного элемента. Разработка таких теорий и соответствующих алгоритмов требует тщательного исследования. Целью настоящей работы является исследование потери устойчивости отдельно стоящих колонн в отсутствии больших перемещений с помощью конструктивной теории второго порядка, а также изучение влияния несовершенств на поведение таких конструктивных элементов.
\end{abstract}

Keywords: колонны, устойчивость структуры, потеря устойчивости, конструктивные элементы

\section{Introduction}

The behaviour of structures in compression differs significantly from their behaviour in tension. The load bearing capacity of a structure in tension is limited by the strength of its material. The load bea- ring capacity of a structure in compression can be limited either by the strength of its material or by instability.

An equilibrium configuration of a structure is singular if the structure can be displaced to a neighbouring equilibrium configuration without change in 
the applied loading. The displacement is assumed to be infinitesimally small. If the load on a structure that is in a singular configuration can be reduced by displacing the structure by a finite increment to a neighbouring equilibrium configuration, this structure is called unstable. If no neighbouring equilibrium configuration with reduced load exists, the structure is called stable even though the configuration is singular.

The order of a theory specifies the approximation that is made in the formulation of the equilibrium equations of a structure. If the equilibrium equations are derived for the reference configuration, the formulation is called a first order theory. If the equilibrium equations are derived for the instant configuration, the formulation is called a second order theory. The governing equations of both first order and second order theory can be either linear or nonlinear, depending on additional assumptions made in the formulations.

First order theories are usually formulated with assumptions that make the theory linear. The solution of the linear governing equations of first order theory for given loads and supports leads to a unique displacement vector. This is illustrated in this paper for a straight bar subjected to an axial load. Because the displacement for given loads and supports is unique, a neighbouring equilibrium configuration with different displacements but equal loads and supports cannot exist. The necessary condition for instability of the structure thus cannot be fulfilled. It is not possible to study the stability of structures with a linear first order theory.

Second order theories can be linear or nonlinear. Nonlinear second order theories are sometimes called third order theories. If the displacements of a structure prior to instability are small relative to the dimensions of the structure, it is sufficient to analyse their stability with a linear second order theory. Such cases are treated in this paper. If the displacements prior to instability are large, the structure must be analysed with a nonlinear second order theory.

The following three cases can be distinguished in second order theory if the governing equations are linear:

(a) The equations are homogeneous: they have nontrivial solutions (solutions that are not null) only if the determinant of their coefficient matrix is null. It is illustrated herein that this approach leads to the Euler buckling load for columns.

(b) The equations are inhomogeneous and the determinant of their coefficient matrix is not equal to null. The structure does not become unstable but undergoes large displacements that limit its serviceability. This is illustrated for columns with imperfections.

(c) The equations are inhomogeneous and the determinant of their coefficient matrix is null. The struc- ture is not in equilibrium for general loadings, but can be in equilibrium for specific loadings. Small geometric imperfections or load perturbations trigger instability under these specific loadings.

Second order theory with nonlinear governing equations is not treated in this paper.

\section{First Order Theory for an Axially Loaded Bar}

Figure 1 shows a straight prismatic bar with modulus of elasticity $E$, whose cross-section has area $A$. The bar is subjected to an axial load $P$ at node $A$. It is supported by a roller in the axial direction at $A$ and by a pin at $B$. The displacements and stresses of the bar under the axial load are to be determined.
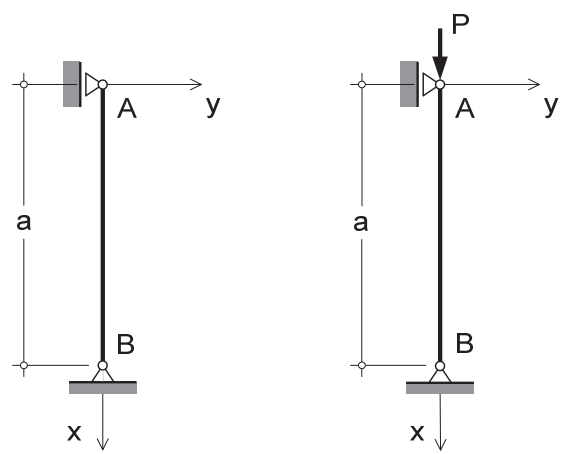

Fig. 1. Reference bar configurations for first order theory

The equilibrium equation is formulated for the bar in its reference configuration: the axis of the bar is considered to be a straight line segment of length $a$ as in the reference configuration on the left of figure 1 . Let the axial force in the bar be $N$ (tension positive). The forces applied to node $A$ are in equilibrium: $N=-P$.

Let the displacement of point $x$ on the axis of the column in the direction of the $x$-axis be $u(x)$. The axial strain $\varepsilon$ on the cross-section of the column is assumed to be constant over the cross-section and equal to the derivative of the displacement $u$ with respect to $x$. The nonlinear terms in the straindisplacement relationship are thus neglected. The axial force in the bar is given by:

$$
N=A E \varepsilon=A E \frac{d u}{d x} .
$$

The axial force $N$ is replaced by $-P$ and the resulting differential equation is solved for the displacement: $u=-(P / A E) x+c$.

The integration constant $c$ follows from the boundary condition that $u=0$ for $x=a$ :

$$
u=(P / A E)(a-x) .
$$


The bar fails when the stress reaches the yield strength of its material. The example shows that linear first order theory does not predict singular configurations of a bar.

\section{Second Order Theory for Euler Columns}

Figure 2 shows a straight prismatic bar with modulus of elasticity $E$, whose cross-section has an area $A$ and a moment of inertia $I$. The bar is subjected to an axial load $P$ at node $B$. It is supported by a pin at $B$ and by a roller in the axial direction at $A$. The displacements and stresses of the bar under the axial load are to be determined.
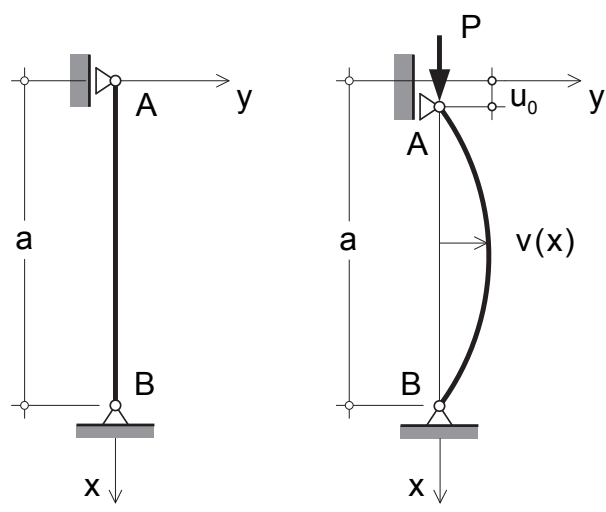

Fig. 2. Reference and instant bar configurations for second order theory

The origin of the Cartesian coordinate system is chosen at node $A$ of the bar. The $x$-axis is directed from node $A$ to node $B$. The $y$-axis is rotated anti-clockwise through an angle of 90 degrees from the $x$-axis. The $z$-axis is orthogonal to the $x$ - and $y$-axes so that the three axes form a right-hand system. This coordinate system will also be used in the following sections.

The equilibrium equation is formulated for the bar in its instant configuration. The axis of the bar in the instant configuration on the right hand side of figure 2 is a curve: the points on the axis of the bar have displaced from their reference location by $u(x)$ in the direction of the $x$-axis and by $v(x)$ in the direction of the $y$-axis.

In the general nonlinear theory, the governing equations for the displacements $u$ and $v$ are coupled because the nonlinear strains are functions of $u$ and $v$. The analysis is simplified by assuming that the displacements are small compared to the dimensions of the column and its cross-section. Separate governing equations can then be formulated for the two displacements.

Additional assumptions are made in the formulation of the governing equation for the axial direction.
The area of the cross-section changes under load due to the Poisson effect. This change is not taken into account. The axial strain $\varepsilon$ is a nonlinear function of the derivatives of displacements $u$ and $v$ :

$$
\varepsilon=\frac{d u}{d x}+\frac{1}{2}\left(\frac{d u}{d x}\right)+\frac{1}{2}\left(\frac{d v}{d x}\right) .
$$

The quadratic terms on the right-hand side of (3) are neglected so that the strain is a linear function of the displacement. Due to these assumptions, solution (2) for the axial displacement $u$ remains valid for second order theory.

Due to the transverse displacement $v$ of the bar, the axial load $P$ causes a bending moment $M$ in the bar. The bending moment acting on a crosssection, whose normal points in the direction of the positive $x$-axis, is considered positive if its vector points in the positive direction of the $z$-axis.

$$
M=-P v \text {. }
$$

The general relationship between the bending moment $M$ and the displacements $u$ and $v$ is highly nonlinear. It is approximated by the relationship between $M$ and $v$ that is formulated in first order beam theory: $M=E I\left(d^{2} v / d x^{2}\right)$.

Substituting the moment $M$ into equation (4) yields:

$$
E I\left(d^{2} v / d x^{2}\right)+P v=0 .
$$

The differential equation (5) is solved with the trigonometric sine function. The integration constants are chosen so that the boundary conditions $v=0$ at $x=0$ and $x=a$ are satisfied:

$$
v=v_{0} \sin \frac{n \pi x}{a} \quad n \in\{1,2, \ldots\} .
$$

Substitution of $v$ from (6) into (5) yields a linear homogeneous equation:

$$
v_{0} \sin \frac{n \pi x}{a}\left(-E I\left(\frac{n \pi}{a}\right)^{2}+P\right)=0 .
$$

Equation (7) is solved by setting either the displacement or the coefficient of the displacement to null:

solution 1:

$$
v_{0}=0
$$

solution 2:

$$
P_{n}=\left(\frac{n \pi}{a}\right)^{2} E I .
$$

It follows from solutions (8) and (9) that the load path of the bar contains bifurcations. The trivial solution $v=0$ is valid for all values of the load $P$. 
The specific values of $P_{n}$ in (9) permit additional equilibrium configurations in which the lateral displacement $v$ is not null. There is a bifurcation in the load path for each value of $n$.

Due to geometric imperfections of the column and perturbations of its loading, the load path in nature will consist of a principal branch with $v=0$ for $P<P_{1}$, and a secondary branch with displacement $v$ given by (6) with $n=1$. The displacement amplitude $v_{0}$ is indeterminate. The load $P_{1}$ is called the Euler buckling load $P_{E}$ for simply supported columns:

$$
P_{E}=\frac{\pi^{2} E I}{a^{2}} .
$$

The example shows that the approach of Euler leads to a linear homogeneous equation for the lateral displacement $v$ that predicts several singular points (9). The point with the smallest absolute value of the load controls the buckling of the column.

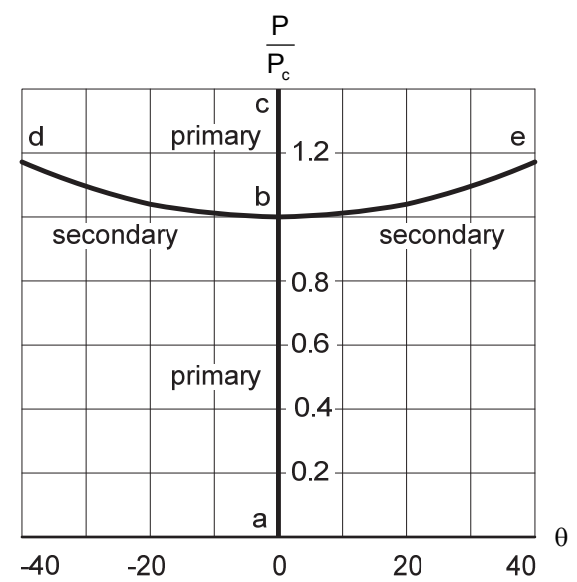

Fig. 3. Bifurcation of the load path of the bar in figure 2

Figure 3 shows the load path of the bar in figure 2 . Point a corresponds to the reference configuration.

\section{Behaviour of \\ Geometrically Imperfect Columns}

Assume that the axis of bar $A B$ in figure 2 is not straight in its reference configuration, but has a geometric imperfection given by the following curve:

$$
g=g_{0} \sin \frac{\pi x}{a},
$$

where $g_{0}$ - specified amplitude of the imperfection.

The equilibrium equation (4) and the governing equation (5) are replaced by:

$$
\begin{gathered}
M=-P(g+v), \\
E I \frac{d^{2} v}{d x^{2}}+P v=-P g .
\end{gathered}
$$
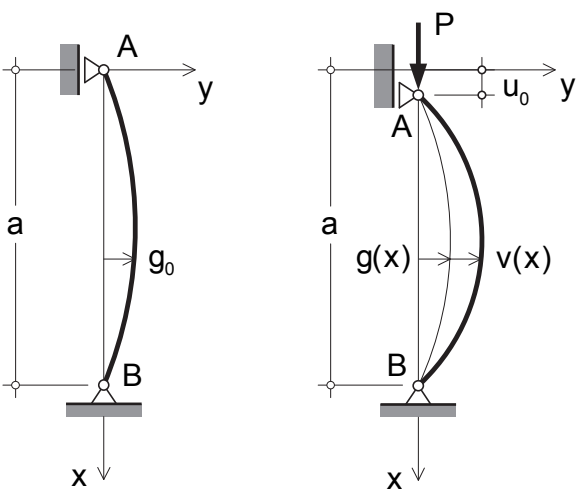

Fig. 4. Column with geometric imperfection

Substitution of the displacement (6) and the imperfection (11) into (13) yields:

$$
-E I\left(\frac{\pi n}{a}\right)^{2} v_{0}+P v_{0}=-P g_{0} .
$$

The governing equation remains linear, but is no longer homogeneous. Consider the special case $n=1$ and define the sum $t(x)$ of the imperfection $g(x)$ and the displacement $v(x)$. Equation (14) leads to:

$$
\frac{t}{g_{0}}=\frac{v_{0}+g_{0}}{g_{0}}=\frac{1}{1-s} \text { with } s=\frac{P}{P_{E}} .
$$

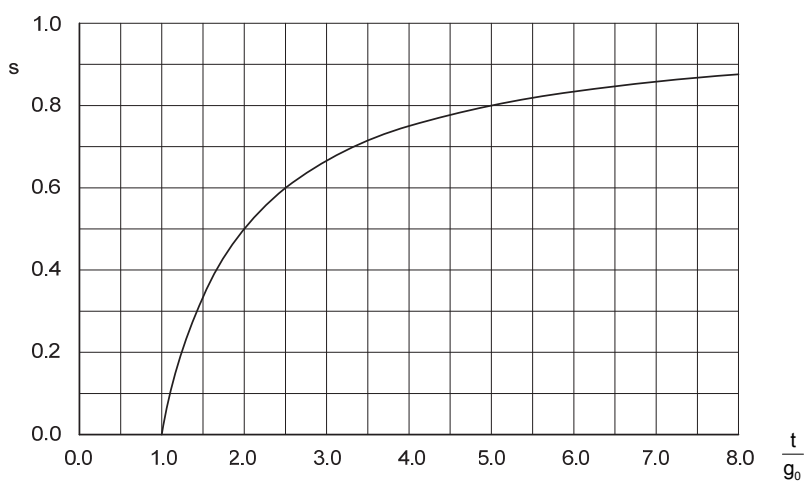

Fig. 5. Load ratio $s=\frac{P}{P_{E}}$ as a function of

$$
\text { the displacement ratio } \frac{t}{g_{0}}
$$

Solution (15) shows that the load path of the column in figure 4 does not contain a singular point. The axis of the column displaces laterally at all load levels. The displacement tends towards infinity as the load on the column tends towards the Euler buckling load $P_{E}$. Figure 5 shows the variation of the displacement ratio $t / g_{0}$ in (15) with the load ratio $s$. The displacement ratio reaches the value 2 for a load ratio of 0.50 , the value of 5 for a load ratio of 0.80 and the value 10 for a load ratio of 0.90 . 


\section{Behaviour of Columns with Load Perturbation}

Assume that the column in figure 6 is subjected to a sinusoidal transverse load $q$ in addition to the axial load $P$ :

$$
q=q_{0} \sin \frac{\pi x}{a}
$$

where $q_{0}$ - amplitude of the perturbation load.
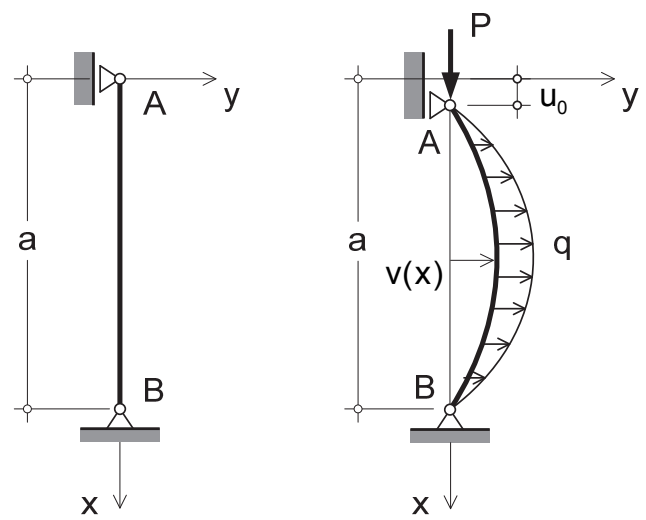

Fig. 6. Column with perturbation load

The equilibrium equation (4) and the governing equation (5) are replaced by:

$$
\begin{aligned}
& M=-P v-q_{0}\left(\frac{a}{\pi}\right)^{2} \sin \frac{\pi x}{a}, \\
& E I \frac{d^{2} v}{d x^{2}}+P v=-q_{0}\left(\frac{a}{\pi}\right)^{2} \sin \frac{\pi x}{a} .
\end{aligned}
$$

Substitution of the displacement (6) into (17) yields the displacement amplitude:

$$
v_{0}=\frac{1}{1-s} \frac{q_{0}}{E I}\left(\frac{a}{\pi}\right)^{4} \text { with } s=\frac{P}{P_{E}} .
$$

The amplitude $v_{t}$ of the displacement due to the transverse load without axial load is:

$$
v_{t}=\frac{q_{0}}{E I}\left(\frac{a}{\pi}\right)^{4}
$$

The amplitude $v_{t}$ is substituted from (19) into (18):

$$
\frac{v_{0}}{v_{t}}=\frac{1}{1-s} \text {. }
$$

Solution (20) shows that the load path of the column in figure 6 does not contain a singular point. The axis of the column displaces laterally at all load levels. The lateral displacement tends towards infinity as the load on the column tends towards the Euler buckling load $P_{E}$. The ratio of the displacement am- plitude $v_{0}$ with axial load to the displacement amplitude $v_{t}$ without the axial load in (20) varies with the load ratio $s$ like the ratio of the lateral displacement $v_{t}$ to the amplitude $g_{0}$ of the geometric imperfection in (15). The displacement tends towards infinity as the load ratio $s$ goes to 1 .

\section{Conclusions}

The study of Euler columns shows that their stability can be studied with two significantly different approaches.

(a) A singular configuration is determined for the column without geometric imperfection and without load perturbation. The load for which this configuration occurs is the buckling load of the column. The column does not displace laterally until the buckling load is reached.

(b) The column is subjected to a geometric imperfection or to a perturbation load in addition to the axial load. The column displaces laterally at all load levels. The displacements cause moments in the column. As the load tends towards the buckling load determined in (a) above, the lateral displacement tends to infinity.

Most of the building codes permit modified forms of both of these approaches to stability theory. In addition, the codes account for the initial stresses in steel members, yielding of the material of the column before it buckles and large displacements that limit serviceability.

(C) Gebre T.H., Al-Sabri S.A.M., Saffia-Doe O., 2018

\section{References}

1. Santamouris M., Mumovic M. (2015). A Handbook of Sustainable Building Design and Engineering, 476.

2. Trahair N.S., Bradford M.A., Nethercot D.A., Gardner L. (2008). The Behaviour and Design of Steel Structure to EC3. Fourth edition. Published by Taylor \& Francis, New York, 490.

3. American Institute of Steel Construction, Steel Construction Manual 13 ${ }^{\text {th }}$ Edition, 2005, 2181.

4. En B.S. (2007). Eurocode 3 - Design of steel structures. Design, 3(1).

5. Building Reaserch, Worked Examples for the Design of Steel Structures BRE SCI Based on BSI \& Eurocode 3. 1.1, 1994.

6. Revisions, January 2003, Manual of Steel Construction Load and Resistance Factor Design, ${ }^{\text {rd }}{ }^{\text {Edition. }}$.

7. Salmon C.G., Johnson J.E., Malh F A. (2009). Steel Structures: Design and Behaviour: Emphasizing Load and Resistance Factor Design.

8. Ghosh K.M. (2010). Practical Design of Steel Structures. 
9. Timoshenko S.P., Gere J. (1963). Theory of elastic stability, 541.

10. Chen W.F., Sohal I. (1995). Plastic Design and Second-Order Analysis of Steel Frames.

11. Marshall T.P. et al. (2015). Design Guide for Low- and Medium-Rise Steel Buildings Institute, AI Mag., 13(1), 217-245.

12. Ray S.S. (1998). Structural Steelwork - Analysis and Design, 582.

13. Wong M.B. (2011). Plastic Analysis and Design of Steel Structures.

14. Claudio Bernuzzi B.C. (2016). Structural Steel Design to Eurocode 3 and AISC Specifications.

15. Williams A. (2011). Steel Structures Design $A S D / L R F D, 545$.

16. American A., Standard N. (2010). For Structural Steel Buildings.

17. Sci, Steel Building Design: Design Data, 2009.

18. Beedle L.S. (1956). Why plastic design, AISCUSC Conf. Plast. Des. Struct. STEEL, No. 205, 1-28.

19. Farkas J., Jármai K. (2013). Optimum Design of Steel Structures, Vol. 46, No. 1-3.

20. Kirke B., Al-Jamel I.H. (2004). Steel Structures Design Manual To AS 4100 First Edition, No. June, 243.

\section{About the authors}

Vera V. Galishnikova - Professor, Director of the Department of Architecture and Civil Engineering, Engineering Academy, Peoples' Friendship University of Russia (RUDN University). Research interests: computational civil engineering, building information modeling, topological computer models of buildings, computational geometry, computational mechanics of complex steel structural systems latticed plates and shells, thin-walled plate and plate-rod structures. nonlinear finite element analysis of space frames, nonlinear stability of structures. Contact: e-mail galishni@gmail.com.

Gebre Tesfaldet Hadgembes - Master of the Department of Architecture and Civil Engineering, Engineering Academy, Peoples' Friendship University of Russia (RUDN University). Research interests: questions of the stability of multi-story buildings elements. Contact: e-mail - tesfaldethg@gmail.com.

Al-Sabri Sahar Abdylrahman Mohammed - Master of the Department of Architecture and Civil Engineering, Engineering Academy, Peoples' Friendship University of Russia (RUDN University). Research interests: metal constructions, computational civil engineering, building information modeling, computational mechanics of complex steel structural systems. Contact: e-mail sahar.alsabri@mail.ru.

Saffia-Doe Osman - Master of the Department of Architecture and Civil Engineering, Engineering Academy,
Peoples' Friendship University of Russia (RUDN University). Research interests: design of steel structure, structure mechanics, stability analysis. Contact: e-mail osmadoe@yahoo.com.

\section{Об авторах}

Галишникова Вера Владимировна - доктор технических наук, профессор, директор департамента архитектуры и строительства Инженерной академии, Российский университет дружбы народов. Область научных интересов: вычислительная строительная инженерия, информационное моделирование зданий, топологические компьютерные модели зданий, вычислительная механика сложных стержневых систем, нелинейные конечноэлементные модели и программные комплексы для расчета пространственных стержневых систем, нелинейная устойчивость конструкций. Контактная информаичия: e-mail-galishni@gmail.com.

Тесфалдет Хадгембес Гебре - магистрант департамента архитектуры и строительства Инженерной академии, Российский университет дружбы народов. Область научных интересов: вопросы устойчивости элементов строительных конструкций. Контактная информация: e-mail - tesfaldethg@gmail.com.

Сахар Абдулрахман Мохаммед Аль-Сабри - магистрант департамента архитектуры и строительства Инженерной академии, Российский университет дружбы народов. Область научных интересов: металлоконструкции, вычислительная строительная инженерия, информационное моделирование зданий, вычислительная механика сложных стержневых систем. Контактная информация: e-mail: - sahar.alsabri@mail.ru.

Осман Саффиа-Дое - магистрант департамента архитектуры и строительства Инженерной академии, Российский университет дружбы народов. Область научных интересов: проектирование стальных конструкций, анализ устойчивости. Контактная информаџия: e-mail-osmadoe@yahoo.com.

\section{For citation}

Galishnikova V.V., Gebre T.H., Al-Sabri S.A.M., Saffia-Doe O. (2018). Second order structural theory for the stability analysis of columns. Structural Mechanics of Engineering Constructions and Buildings. 14(3), 192-197. DOI: 10.22363/1815-5235-2018-14-3-192-197.

\section{Для цитирования}

Galishnikova V.V., Gebre T.H., Al-Sabri S.A.M., Saffia-Doe $O$. Second order structural theory for the stability analysis of columns // Строительная механика инженерных конструкций и сооружений. 2018. Т. 14. № 3. C. 192-197. DOI: 10.22363/1815-5235-2018-14-3-192-197. 